\title{
Qualitative and Quantitative Analysis of Dexamethasone in Rheumatic Pain Herbal Medicine Using Thin Layer Chromatography (TLC) - Densitometry
}

\author{
Desy Ayu Irma Permatasari ${ }^{1 *}$; Novita Kurniasri'; Muladi Putra Mahardika³ \\ ${ }_{1,2}$ Departement of Pharmacy, Faculty of Health Science, Universitas Duta Bangsa Surakarta, Jl. Pinang, Cemani, Grogol, Sukoharjo, Jawa \\ Tengah 57552. \\ 3 Departement of Pharmacy, Politeknik Harapan Bersama, J. Mataram, No 9, Tegal, Jawa Tengah 52147.
}

\begin{abstract}
Chemical medicine is chemical substances that is used as the main ingredient of chemical drugs. This compound is usually added to herbal medicine preparation to strengthen the indication of the traditional medicine.Chemical medicine was prohibited from being added to traditional medicinal preparations. But in reality, a lot of medicinal herbs could have contained medicinal chemicals on the market sale. This purpose of this research was to know the chemical contamination of the dexamethasone also the concentration contained in the rheumatic pain herbal medicine. This research was used three kind of rheumatic pain herbal medicine sample to identify dexamethasone, the sample code is $S_{1}, S_{2}$, and $S_{3}$. The analysis of qualitative method are organoleptic test, FTIR characteristic test, TLC evaluation. The analysis of quantitative were purposed to know the dexamethasone concentration contained on the rheumatic pain herbal medicine using TLC-Densitometric method. The result show that the three sample of rheumathic pain herbal medicine were contaminated by dexamethasone chemical medicine. Based on organoleptic test, the results show color, smell, and taste. Characterization of the dexamethasone using FTIR were to know functional groups of dexamethasone contained in the rheumatic pain herbal medicine sample, the functional groups of the sample $S_{1}, S_{2}$, and $S_{3}$ were compared to dexamethasone standard. To identify of TLC method, obtained Rf value of dexamethasone standard and the sample, visualizing a stain color purplefluorescence on the UV $254 \mathrm{~nm}$. The analysis of quantitative dexamethasone concentration using TLC-Densitometric showed the presence of dexamethasone in the sample for $\mathrm{S}_{1}, \mathrm{~S}_{2}$ and $\mathrm{S}_{3}$. The concetration of dexamethasone obtained of sample $\mathrm{S}_{1}, \mathrm{~S}_{2}$, $\mathrm{S}_{3}$ were $1014.64 \mu \mathrm{g} / \mathrm{g} ; 131.15 \mu \mathrm{g} / \mathrm{g} ; 135.54 \mu \mathrm{g} / \mathrm{g}$ respectively.
\end{abstract}

Keywords: dexamethasone; rheumatic pain herbal medicine; TLCdensitometric; quantitave analysis, qualitative analysis

\footnotetext{
*Corresponding author, e-mail: desyayu_permatasari@udb.ac.id
}

\section{Data of article}

Received : 31 July 2021

Reviewed : 05 Aug 2021

Accepted : 24 Aug 2021

DOI

10.18196/jfaps.v2i1.12450

Type of article:

Research 


\section{INTRODUCTION}

The lower middle class widely uses traditional medicines and medicinal plants due to their affordable price. Another reason people use traditional medicine is that medicinal plants or traditional medicine are relatively safer than synthetic medicine. The natural efficacy and purity of traditional medicines are frequently tainted by irresponsible parties, especially traditional medicine manufacturers who are only looking for financial gain without considering the purity and risks of the content of traditional medicines. Mixing herbs with medicinal chemicals is also done to make these herbs more efficacious instantly ${ }^{1}$. The regulations in Indonesia require that natural medicines and herbs are not allowed to contain chemical medicine. It is hazardous as natural medicines in herbal medicine are often used for a long time and at doses that cannot be ascertained, although the healing effect is immediately felt. However, the uncontrolled use of BKO with doses that cannot be ascertained can cause serious side effects, ranging from nausea, diarrhea, dizziness, headache, visual disturbances, chest pain to severe organ damage such as liver damage, kidney failure, heart failure, and even death ${ }^{2}$.

Furthermore, thin-layer chromatography is the separation of the components of a compound from another compound where the components will be distributed between two phases, namely the stationary phase and the mobile phase. The compound's polarity will last longer; otherwise, the component interacts less with the faster-moving mobile phase. The stages in TLC, the analysis stages, start from spotting samples and standards on the TLC plate until direct visual observation under $254 \mathrm{~nm}$ UV light for spotting separation components 3 .

Based on this background, this research aims to analyze dexamethasone's qualitative and quantitative contamination in rheumatic pain herbal medicine sold in Mungkid District, Magelang. Dexamethasone was chosen as it is often added to herbal pain relievers such as rheumatic herbs and herbs for aches and pains. This research provided new information about the contamination of chemical medicine in traditional medicine.

\section{METHOD}

\section{Tools and Materials}

The tools used in this study included a weight analytical (Ohaus), $10 \mathrm{ml}$ volumetric flask (Pyrex), $20 \mathrm{ml}$ measuring cup (Pyrex), beaker glass (Pyrex), capillary tube, boiling stone, micropipette, chamber, TLC plate $\mathrm{GF}_{254}$ (Merck), UV light 254nm, Vortex Mixer (B-One), centrifuge, FTIR (Shimadzu), and TLCDensitometry Scanner (Camag).

Materials used in this research included rheumatic pain herbal medicine, standard dexamethasone pro analysis (BPOM), 96 $\%$ ethanol pro analysis (Merck), chloroform pro analysis (Merck), tolvene pro analysis (Merck), ethyl acetate pro analysis (Merck), methanol pro analysis (Merck), and n-hexane pro analysis (Merck). In the mobile phase, the material used was a mixture of ethyl acetate, toluene, and methanol ratio of 45:55:1. Meanwhile, in the stationary phase, it used a silica gel TLC plate GF254.

\section{Sample}

The sample in this study were three kinds of rheumatic herbal medicine obtained from different manufacturers purchased from several market stalls for traditional 
herbal aches and pains. This research is experimental research conducted in the Pharmacy Laboratory at Universitas Duta Bangsa Surakarta, Pharmacy Laboratory at Politeknik Indonusa Surakarta, and UGM Integrated Research and Testing Laboratory4.

\section{Organoleptic test}

Each herbal medicine product included ingredients and organoleptically tested shape, color, and taste 5 .

\section{Sample Preparation}

The sample in the herbal medicine weighed approximately $100 \mathrm{mg}$. It was put into a beaker, and then a solution of chloroform: methanol (9:1) approximately $10 \mathrm{ml}$ was added. It was sonicated for 20 minutes and filtered. Furthermore, the liquid extract from the herbal medicine sample was collected. The extract was evaporated on a water bath to dry. The remaining evaporation was dissolved with $5 \mathrm{ml}^{\circ}$ of methanol ${ }^{6}$.

\section{Preparation of Dexamethasone Comparative Standards}

The standard for dexamethasone weighed $10 \mathrm{mg}$ and was put in a volumetric flask. It was dissolved with $96 \%$ ethanol to $10 \mathrm{ml}$ and then homogenized ${ }^{6}$.

\section{Qualitative test with thin layer} chromatography method

Sample solution and dexamethasone standard were spotted on the GF254 silica gel TLC plate. The eluent was a mixed solvent of ethyl acetate: toluene: methanol (45:55:1) that was put into the chamber. After the eluent reached the mark, it was removed and dried. The resulting chromatogram was observed for stains under ultraviolet (UV) light with a wavelength of $254 \mathrm{~nm}$. Furthermore, the stains were found in the sample and the standard. The Rf value of the sample and standard was later calculated ${ }^{2}$.

\section{Quantitative Analysis of Dexamethasone by TLC-Densitometry}

\section{a. Preparation of standard solutions}

The standard solution was prepared carefully by weighing approximately 10 $\mathrm{mg}$ of dexamethasone and dissolving it with ethanol up to $10 \mathrm{ml}$ to obtain a dexamethasone stock solution with a concentration of 1000 ppm. Furthermore, a $2.5 \mathrm{ml}$ pipette was put into a $5 \mathrm{ml}$ measuring flask filled with $96 \%$ of ethanol $2.5 \mathrm{ml}$ so that a standard solution with a concentration of 500 ppm was obtained?

\section{b. Preparation of sample solution}

The sample of macerated herbal medicine was weighed $100 \mathrm{mg}$ and then dissolved in $1 \mathrm{ml}$ of $96 \%$ ethanol. It was mixed with vortex for 2 minutes and was sonicated for 60 minutes. Samples were macerated overnight. It was put into vortex and centrifuge for 5 minutes to take the supernatant ${ }^{4}$.

\section{c. Determination of dexamethasone levels in samples}

The standard solutions and samples included concentrations of $100 \mu \mathrm{g}, 200$ $\mu \mathrm{g}, 400 \mu \mathrm{g}, 600 \mu \mathrm{g}, 800 \mu \mathrm{g}, 1000 \mu \mathrm{g}$. The sample spot was then done by micropipette with a concentration of 5 $\mu L$ on the TLC GF254 plate. The plates were eluted in a chamber containing elvent ethyl acetate: tolvene: ethanol: n-hexane (51:12:3:15) ${ }^{4}$. Separated spots were observed with a UV lamp of 254 
$\mathrm{nm}$ and measured by TLCDensitometry at a maximum wavelength of $240 \mathrm{~nm}$, and the scan results were analyzed ${ }^{8}$.

\section{Characterization with FTIR}

The characterization of the FTIR spectrum aimed to determine the functional groups of the identified organic compounds, namely dexamethasone in rheumatic pain herbal medicine. The sample $\mathrm{S}_{1}, \mathrm{~S}_{2}$, and S3 powder containing dexamethasone were grounded using $\mathrm{KBr}$ into a solid pallet. Spectra were recorded at a wavelength of $4000-650 \mathrm{~cm}-1$ to obtain functional group bands from the sample. The spectra were recorded first to read the background (air background). Furthermore, the sample was inserted into the sample holder and left for a few moments for the sample scanning to finish and get detailed spectra data.

\section{RESULTS AND DISCUSSION}

\section{Sample Description}

The description below is the difference based on the brand, composition, efficacy or use, dosage, and the registration status with BPOM.

Table 1. Description of the Samples of Jamu Aches and Pains

\begin{tabular}{|c|c|}
\hline Sample and Picture & Ingredients \\
\hline (S1) & $\begin{array}{ll}\text { - } & \text { Royal Jelly } \\
\text { - } & \text { Foeniculi Fructus } \\
\text { - } & \text { Liqustici Radic } \\
\text { - } & \text { Conidii Radic } \\
& \end{array}$ \\
\hline & $\begin{array}{ll}\text { - } & \text { Kaempferiae rhizome } \\
\text { - } & \text { Curcumae rhizome } \\
\text { - } & \text { Retrofracti fructus } \\
\text { - } & \text { Zingiberis purpurae rhizome } \\
\text { - } & \text { Parkiae semen }\end{array}$ \\
\hline (S3) & $\begin{array}{ll}\text { - } & \text { Kaempferiae rhizome } \\
\text { - } & \text { Curcumae rhizome } \\
\text { - } & \text { Retrofracti fructus } \\
\text { - } & \text { Zingiberis purpurae rhizome } \\
\text { - } & \text { Zingiberis aromaticae rhizome } \\
\text { - } & \text { Parkiae semen }\end{array}$ \\
\hline
\end{tabular}

\section{Dexamethasone Qualitative Analysis Organoleptic Test}

The first test carried out in the qualitative analysis was the organoleptic test. In the organoleptic test, the aim is to determine the tested sample's color, taste, dosage form, and odor 5 . 
Table 2. Organoleptic Test Results of Rheumatic Pain Herbal Medicine Samples

\begin{tabular}{llllll}
\hline $\begin{array}{l}\text { Herbal } \\
\text { Samples }\end{array}$ & Form & Color & Scent & Flavor & Picture \\
\hline Sample S1 & Powder & Pale-yellow & Herb & Plain & \\
Sample S2 & Powder & Pale-yellow & Herb & Sweet & \\
& & & & & \\
& & & & & \\
& & & & & \\
& & & & & \\
Sample S3 & Powder & Light- & Herb & Bittersweet & \\
& & brown & & \\
\hline
\end{tabular}

\section{Characterization with FTIR}

The characterization of the FTIR spectrum aims to determine the functional groups of the identified organic compounds, namely dexamethasone in rheumatic pain herbal

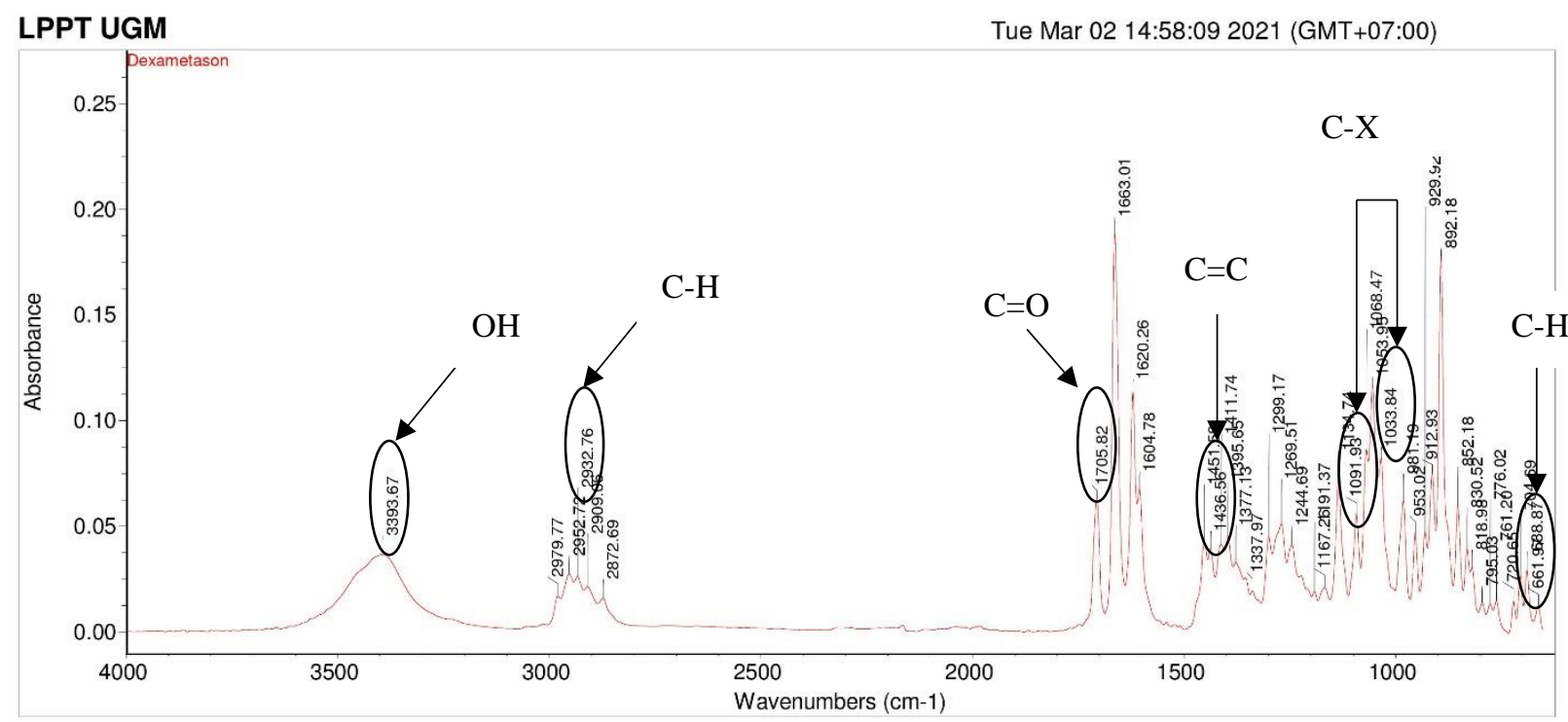

medicine. Basically, the infrared spectrum is used to determine the type of functional group of a compound. In the standard compound of dexamethasone, several groups can show peaks in the IR spectrum.

Figure 1. FTIR Spectrum on Dexamethasone Standard

The rheumatic pain herbal medicine sample carried out using FTIR spectrophotometer analysis should not contain dexamethasone as it will affect the predicted concentration value to be greater than the concentration

intentionally added by the researcher when reading FTIR and that the 
concentration value is not valid. Thus, it is necessary to conduct qualitative analysis to prove that the sample of herbal pain relief does not contain chemicals drugs, considering that many herbal products sold in the market have been mixed with chemicals drugs such as dexamethasone ${ }^{9}$. Based on the results of standard characterization of dexamethasone and samples of rheumatic pain herbal medicine using FTIR, it was shown that there was a possibility that all samples of rheumatic pain herbal medicine contained dexamethasone, as evidenced by the functional group comparisons to dexamethasone standard obtaining the same functional groups, namely $\mathrm{CH}, \mathrm{OH}$, $\mathrm{C}=\mathrm{O}, \mathrm{C}=\mathrm{C}$ and $\mathrm{CX}{ }^{8}$. The results of the FTIR spectra and the description of the identification of the functional groups from the standard dexamethasone and samples of rheumatic pain herbal medicine $\mathrm{S}_{1}, \mathrm{~S}_{2}$, and $\mathrm{S}_{3}$ are shown in Picture 1, 2, 3, and 4, respectively.

Table 3. Interpretation of FTIR Spectra on $\mathrm{S}_{1}, \mathrm{~S}_{2}, \mathrm{~S}_{3}$, and dexamethasone standard

\begin{tabular}{|c|c|c|c|c|c|c|}
\hline \multirow{2}{*}{$\begin{array}{c}\text { Wavelength } \\
\left(\mathrm{cm}^{-1}\right)[9]\end{array}$} & \multicolumn{4}{|c|}{ Sample wavelength $\left(\mathrm{cm}^{-1}\right)$} & \multirow{2}{*}{ Intencity } & \multirow{2}{*}{$\begin{array}{c}\text { Functional } \\
\text { Group }\end{array}$} \\
\hline & $S_{1}$ & $S_{2}$ & $S_{3}$ & Standard & & \\
\hline $3570-3200$ & 3282.74 & 3318.07 & 3283.76 & 3393.67 & Strong & $\begin{array}{l}\mathrm{O}-\mathrm{H} \\
\text { (Hydroxyl) }\end{array}$ \\
\hline $3000-2850$ & 2921.12 & $2924 \cdot 37$ & 2925.05 & 2932.76 & Strong & C-H (Alkene) \\
\hline $1820-1600$ & 1635.09 & 1636.43 & 1633.45 & 1705.82 & Strong & $\begin{array}{l}\mathrm{C}=\mathrm{O} \\
\text { (Ketone) }\end{array}$ \\
\hline $1400-1600$ & 1418.12 & 1431.55 & 1418.33 & 1436.56 & $\begin{array}{ll}\text { Medium } \\
\text { Weak }\end{array}$ & $\begin{array}{l}\mathrm{C}=\mathrm{C} \\
\text { (Aromatic) }\end{array}$ \\
\hline $1400-1000$ & 1076.02 & 1075.57 & 1075.27 & 1091.93 & Strong & $\begin{array}{l}\mathrm{C}-\mathrm{X} \\
\text { (Flouride) }\end{array}$ \\
\hline $1400-1000$ & 1012.54 & 1011.22 & 1011.43 & 1033.84 & Strong & $\begin{array}{l}\mathrm{C}-\mathrm{X} \\
\text { (Flouride) }\end{array}$ \\
\hline $1000-650$ & 666.14 & 666.90 & 666.30 & 661.98 & Strong & C-H (Alkene) \\
\hline
\end{tabular}

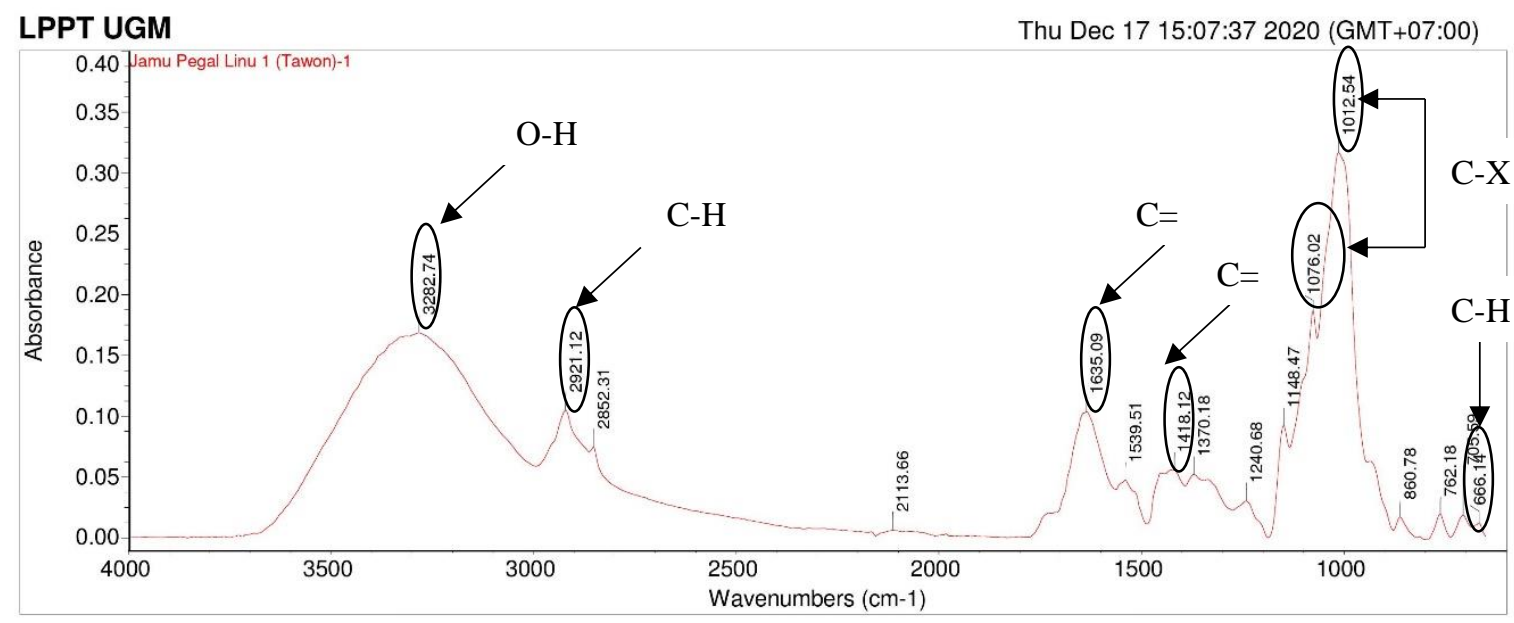

Figure 2. FTIR Spectrum on Sample S1 


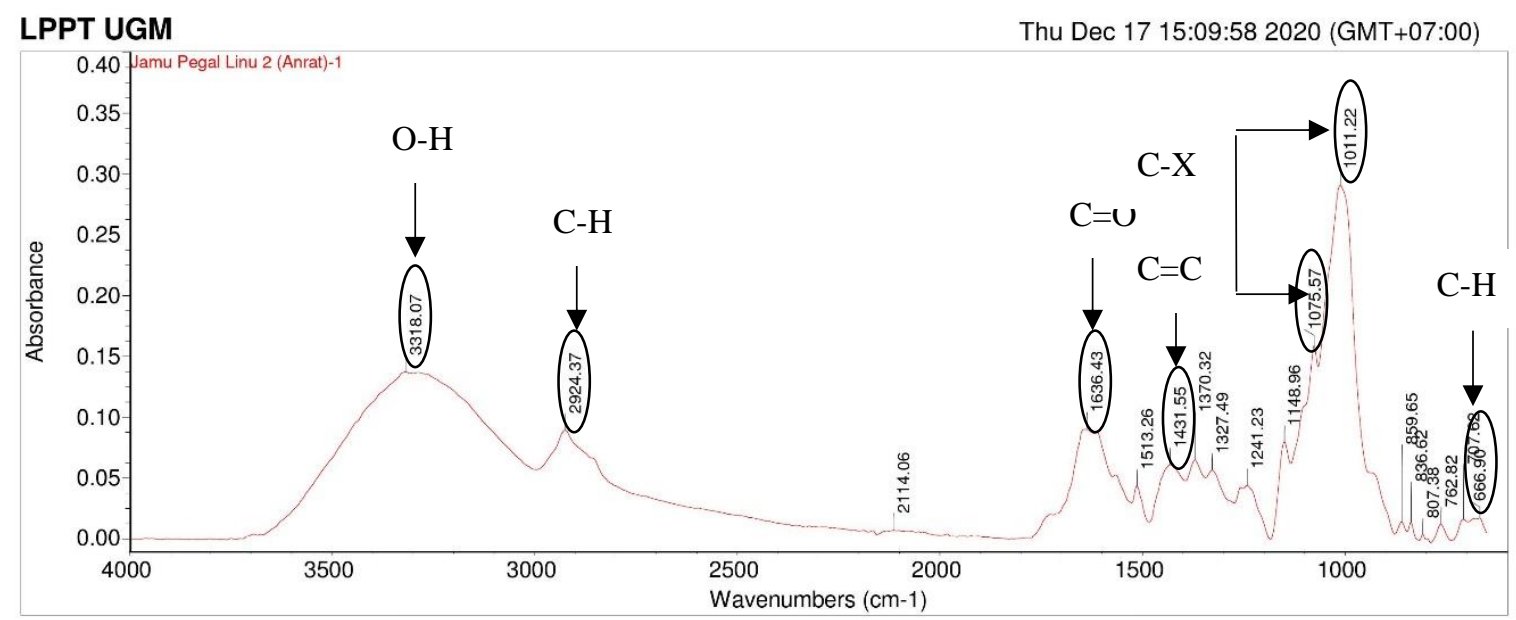

Figure 3. FTIR Spectrum on Sample S2

\section{LPPT UGM}

Thu Dec 17 15:10:47 2020 (GMT+07:00)

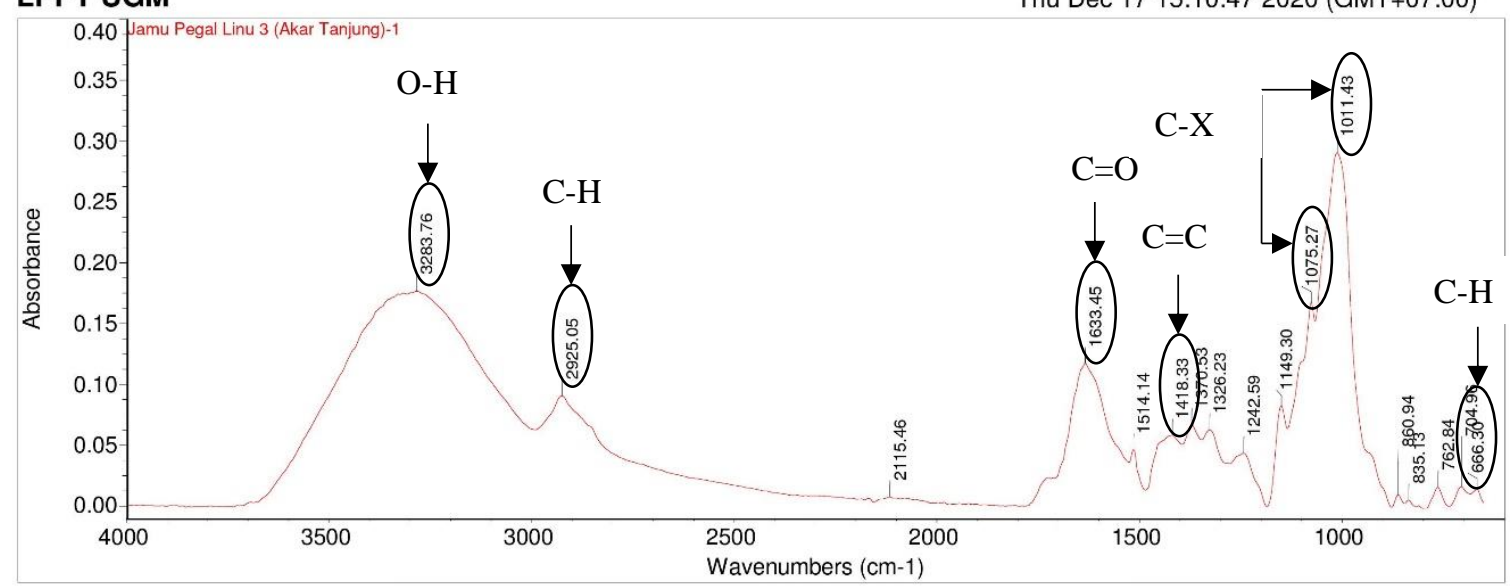

Figure 4. FTIR Spectrum on Sample S3

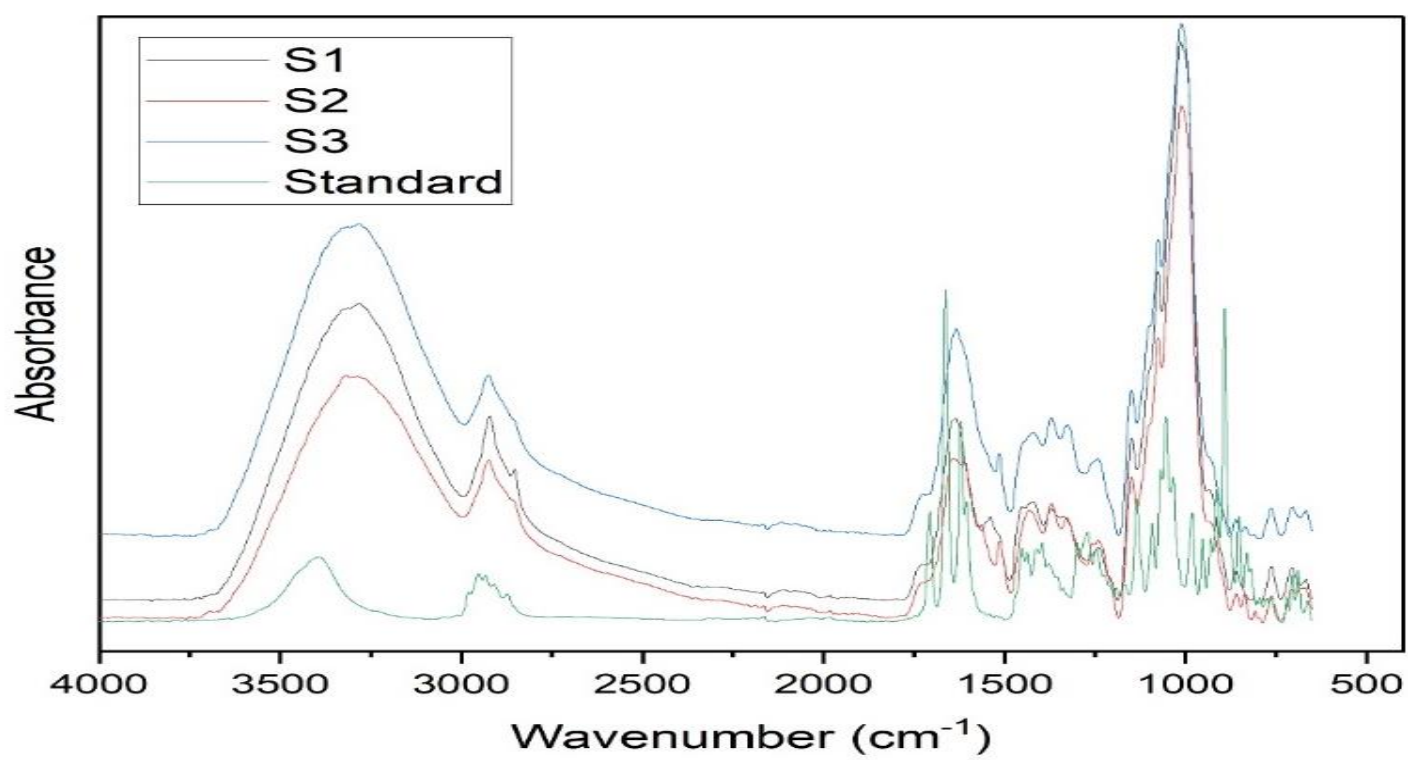

Figure 5. Overlay Spectra of FTIR on Sample $S_{1}, S_{2}$, and $S_{3}$ 
The overlayed spectra of FTIR on samples $\mathrm{S}_{1}, \mathrm{~S}_{2}$, and $\mathrm{S}_{3}$ showed that all the samples had the same peak. It is expected that all the samples were contaminated with chemical medicine, dexamethasone.

Thin Layer Chromatography Test

The third test using the TLC method was carried out to separate the substances contained in the sample and the standard. It has the advantage of better identification accuracy and determines

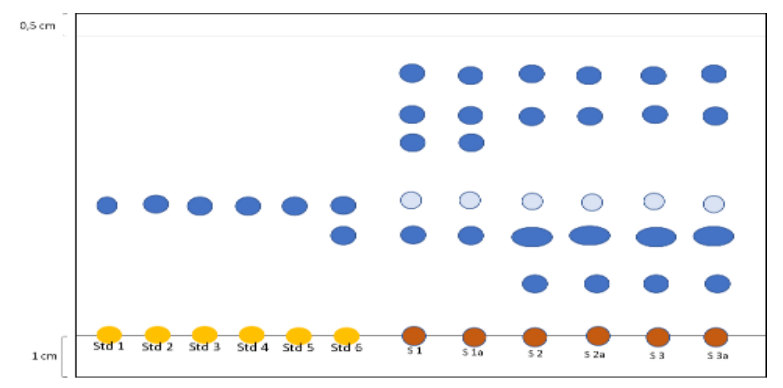

the $\mathrm{Rf}$ value between the sample and the dexamethasone standard ${ }^{10}$.

The test was carried out by spotting the dexamethasone standard solution and samples $\mathrm{S}_{1}, \mathrm{~S}_{2}, \mathrm{~S}_{3}$ on one plate with six replications of the standard dexamethasone solution and each sample $\mathrm{S}_{1}, \mathrm{~S}_{2}, \mathrm{~S}_{3}$ with two replications. The following are the results of detecting the TLC plate generated by the spot on UV $254 \mathrm{~nm}$ observation.

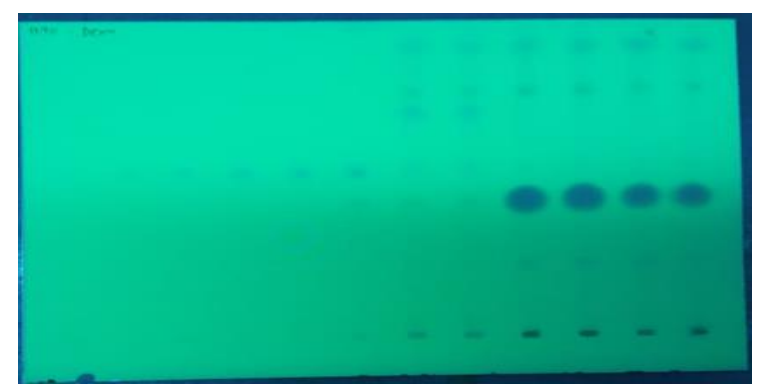

\section{Description :}

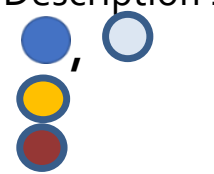

= Spot Standard Dexamethason and Sample

= Spot Standard Dexamethasone with six replications

= Spot Sample with two replications

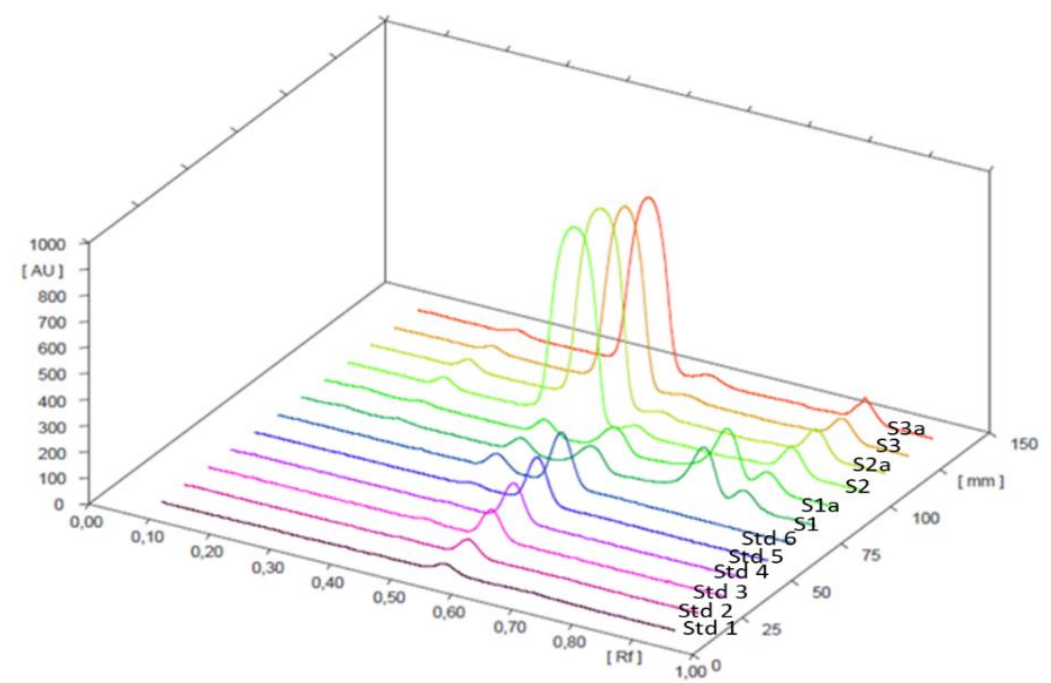

Figure 6. TLC evaluation on Rheumatic Pain Herbal Medicine Samples

Chromatograms resulting from qualitative analysis by TLC-Densitometry consisting of Std 1-6 is standard dexamethasone with the concentration of $100 \mu \mathrm{g}, 200 \mu \mathrm{g}, 400$ $\mu \mathrm{g}, 600 \mu \mathrm{g}, 800 \mu \mathrm{g}, 1000 \mu \mathrm{g}$, respectively. The S1-S1a is a sample of herbal medicine
S1 with two replications. Meanwhile, S2S2a is herbal medicine sample $S_{2}$ with two replications, and $\mathrm{S}_{3}-\mathrm{S}_{3} \mathrm{a}$ is herbal medicine sample $S_{3}$ with two replications. 


\section{Quantitative Analysis}

Table 4. Thin Layer Chromatography (TLC) Test Results of Rheumatic Pain Herbal Medicine Samples o.

\begin{tabular}{|c|c|c|c|c|c|c|}
\hline $\begin{array}{l}\text { Sample and } \\
\text { Standard }\end{array}$ & Visual color & $\begin{array}{c}\text { UV } 254 \\
\mathrm{~nm}\end{array}$ & $\begin{array}{l}\text { Solute } \\
(\mathrm{cm})\end{array}$ & $\begin{array}{l}\text { Eluent } \\
(\mathrm{cm})\end{array}$ & $\begin{array}{c}\text { Rf } \\
\text { Value }\end{array}$ & Result \\
\hline \multicolumn{7}{|c|}{ Dexamethason } \\
\hline $\begin{array}{c}\text { Standard } \\
\text { Dexamethason }\end{array}$ & Pale-purple & Flouresence & 4.80 & 8.50 & 0.56 & + \\
\hline \multicolumn{7}{|c|}{ Sampel S1 } \\
\hline Spot 1 & Pale-purple & Flouresence & 3.90 & 8.50 & 0.45 & - \\
\hline Spot 2 & Pale-purple & Flouresence & 4.90 & 8.50 & 0.57 & + \\
\hline Spot 3 & Pale-purple & Flouresence & 6.40 & 8.50 & 0.75 & - \\
\hline Spot 4 & Pale-purple & Flouresence & 7.00 & 8.50 & 0.82 & - \\
\hline Spot 5 & Pale-purple & Flouresence & 8.30 & 8.50 & 0.97 & - \\
\hline \multicolumn{7}{|c|}{ Sample 2} \\
\hline Spot 1 & Pale-purple & Flouresence & 2.10 & 8.50 & 0.24 & - \\
\hline Spot 2 & Pale-purple & Flouresence & 4.00 & 8.50 & 0.47 & - \\
\hline Spot 3 & Pale-purple & Flouresence & 4.90 & 8.50 & 0.57 & + \\
\hline Spot 4 & Pale-purple & Flouresence & 7.00 & 8.50 & 0.82 & - \\
\hline Spot 5 & Pale-purple & Flouresence & 8.30 & 8.50 & 0.97 & - \\
\hline \multicolumn{7}{|c|}{ Sample 3} \\
\hline Spot 1 & Pale-purple & Flouresence & 2.10 & 8.50 & 0.24 & - \\
\hline Spot 2 & Pale-purple & Flouresence & 4.00 & 8.50 & 0.47 & - \\
\hline Spot 3 & Pale-purple & Flouresence & 4.90 & 8.50 & 0.57 & + \\
\hline Spot 4 & Pale-purple & Flouresence & 7.00 & 8.50 & 0.82 & - \\
\hline Spot 5 & Pale-purple & Flouresence & 8.30 & 8.50 & 0.97 & - \\
\hline
\end{tabular}




\section{TLC-Densitometry Evaluation}

The determination of the standard curve aims to obtain a line equation which can later be used for quantitative analysis of a compound. The standard curve of dexamethasone can be seen in Picture 7. The results of making the standard curve of dexamethasone showed $\mathrm{R}^{2}=0.9937$ with a linear equation $y=13.845 x+942.46$. The best $r$-value is close to $0.99^{\text {[11] }}$. Meanwhile, the b-value obtained on the standard curve of dexamethasone was
13.845. The value of $b$ is the slope indicating the sensitivity. It means that the greater value of $b$ indicates the sensitive result of the method. Moreover, the value of $a$, on the standard curve of dexamethasone, was 942.4. The value of a means selectivity, indicating that the smaller the value of a is, the more selective the measurement will be. The TLCDensitometry method is selective for determining the concentration of dexamethasone.

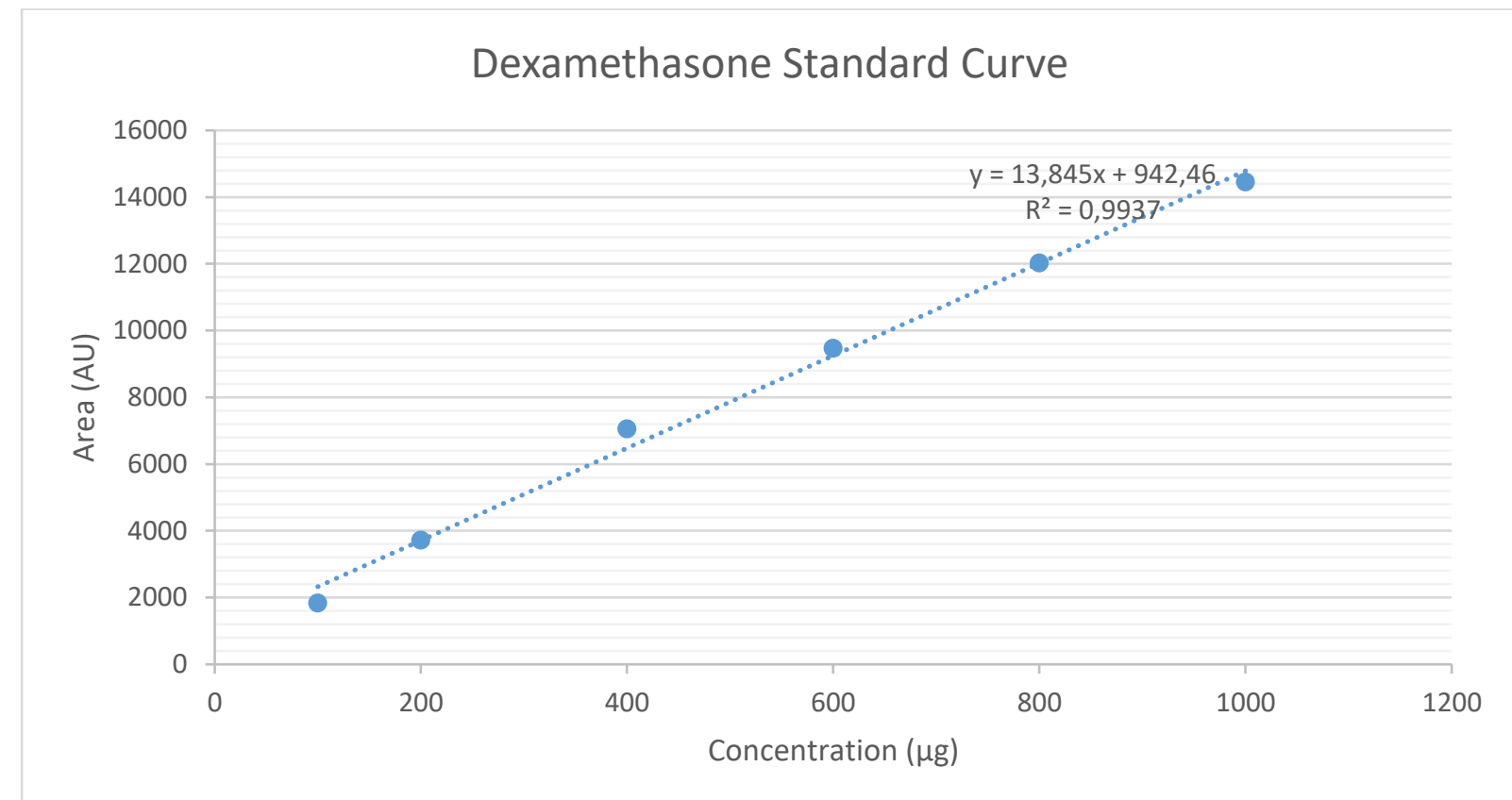

Figure 7. Dexamethasone Standard Curve

The alignment of the regression model can be explained using the value of $R^{2}$. If the $R^{2}$ value is close to 1 , it means the regression model is getting better. $\mathrm{R}^{2}$ value has the characteristic where the value is always positive. The maximum $R^{2}$ value is 1 . The result obtained in this study showed an $\mathrm{R}_{2}$ value of 0.9937 , indicating a good meaning of conformity.

After obtaining the line equation to identify the dexamethasone content in the sample, the testing was carried out to determine the area of the sample so that the " $y$ " value can be obtained. The result of the analysis of the samples is then interpreted in the form of chromatograms. Based on Table 5, in finding out the dexamethasone content in the sample, the area value entered as the " $y$ " value in the line equation obtained previously. The dexamethasone level in the sample can be calculated using the line equation based on the previous line equation.

In the $\mathrm{S}_{1}$ herbal medicine sample, the dexamethasone level was $1014.64 \mu \mathrm{g} / \mathrm{g}$, and in the $\mathrm{S}_{2}$ herbal medicine, the concentration was $131.15 \mu \mathrm{g} / \mathrm{g}$. In the $\mathrm{S}_{3}$ herbal medicine, the levels obtained were $135.54 \mu \mathrm{g} / \mathrm{g}$. 
Table 5. Result of the Qualitative Analysis using TLC-Densitometry

\begin{tabular}{|c|c|c|c|c|c|c|}
\hline Sample & Replication & $\begin{array}{c}\text { Concentration } \\
\text { Sample }(\mu \mathrm{g})\end{array}$ & AUC & $\begin{array}{l}\text { Dexamethason } \\
\text { in sample }(\mu \mathrm{g})\end{array}$ & $\begin{array}{c}\text { Concentration } \\
\text { of } \\
\text { dexamethason } \\
(\mu \mathrm{g} / \mathrm{g})\end{array}$ & $\begin{array}{l}\text { Mean } \\
(\mu g / g)\end{array}$ \\
\hline \multirow{2}{*}{$\mathrm{S}_{1}$} & 1 & 505 & 7905.33 & 0.503 & 995.87 & \multirow{2}{*}{1014.64} \\
\hline & 2 & 504.5 & 8160.74 & 0.521 & 1033.42 & \\
\hline \multirow{2}{*}{$\mathrm{S}_{2}$} & 1 & 501 & 2188.62 & 0.090 & 179.65 & \multirow{2}{*}{131.15} \\
\hline & 2 & 504 & 1519.28 & 0.042 & 82.66 & \\
\hline \multirow{2}{*}{$S_{3}$} & 1 & 514 & 1694.84 & 0.054 & 105.72 & \multirow{2}{*}{135.54} \\
\hline & 2 & 513.5 & 2118.13 & 0.085 & 165.36 & \\
\hline
\end{tabular}

Validation of the analytical method is used to show that the analytical method is feasible and is expected to obtain reliable results. Furthermore, the precision parameters are used to identify the closeness of the measurement results under the same conditions. In this study, standard solutions used a concentration of $100 \mu \mathrm{g}, 200 \mu \mathrm{g}, 400 \mu \mathrm{g}, 600 \mu \mathrm{g}, 800 \mu \mathrm{g}$,
$1000 \mu \mathrm{g}$. This research was conducted with two replications.

Based on the table above, the three rheumatic pain herbal medicine samples contained the chemical medicine of dexamethasone, whereas there should be no medicinal chemicals in herbal medicine.

Table 6. The Results of the Organoleptic test, FTIR test, and TLC-Densitometry Test

\begin{tabular}{cccccc}
\hline Sample & $\begin{array}{c}\text { Organoleptic } \\
\text { Test }\end{array}$ & FTIR & TLC & $\begin{array}{c}\text { TLC- } \\
\text { Densitometry }\end{array}$ & Conclusion \\
\hline $\mathrm{S}_{1}$ & - & + & + & + & (Positive) + \\
\hline $\mathrm{S}_{2}$ & - & + & + & + & (Positive) + \\
\hline $\mathrm{S}_{3}$ & - & + & + & + & (Positive) + \\
\hline
\end{tabular}

Based on the result in Table 6 above, the observation of organoleptic tests, TLC tests, FTIR tests, and TLC-Densitometry test can conclude that the three samples had positive results containing the chemical contamination of the dexamethasone. In terms of the safety aspect, it is an absolute requirement that must be met by herbal medicine, according to the Minister of Health Regulation No. 007 of 2012 concerning the registration of traditional medicines, including using materials that meet safety and quality requirements. It explains that the efficacy has to be empirically and scientifically proven. Furthermore, the production process must meet the requirements for a suitable traditional medicine manufacturing method. It must not contain any medicinal chemicals, narcotics or psychotropic substances, and other materials that, based on health considerations or based on research, can endanger health ${ }^{[16]}$. In relation to it, the factor of herbal medicine manufacturers adding medicinal chemicals is to increase the efficacy of herbal medicine and provide a more instant herbal effect than those that do not contain medicinal chemicals.

\section{CONCLUSION}

Traditional herbal medicine basically should not be mixed with chemical 
medicine, such as dexamethasone. Based on the result of this study, there was contamination of the chemical medicine, dexamethasone, in the samples of herbal aches and pains $\mathrm{S}_{1}, \mathrm{~S}_{2}$, and $\mathrm{S}_{3}$ after the evaluation with qualitative and quantitative analysis such as organoleptic tests, characterization with FTIR, Thin Layer Chromatography, and TLCDensitometry. The concentration of dexamethasone in the $\mathrm{S}_{1}, \mathrm{~S}_{2}$, and $\mathrm{S}_{3}$ herbal pain relief were $1014.64 \mu \mathrm{g} / \mathrm{g}$, $131.15 \mu \mathrm{g} / \mathrm{g}$, and $135.54 \mu \mathrm{g} / \mathrm{g}$. Furthermore, the highest concentration of the chemical medicine of dexamethasone was found in herbal medicine $\mathrm{S}_{1}$.

\section{CONFLICT OF INTEREST}

There are no conflicts of interest in the research.

\section{REFERENCES}

1. Harmanto, N., \& Subroto, M. (2007). Pilih Jamu dan Herbal Tanpa Efek Samping. Cetakan Pertama: Elekmedia.

2. Permadi, Y. W., Slamet., \& Safitri, E. S. (2018). Identifikasi Kandungan Bahan Kimia Obat pada Jamu Gemuk Badan Pada Merek Jamu Kianpi Pil dan Jamu Gemuk Gunasehat dengan Metode KLT. URECOL STIKES PKU Muhammadiyah Pekajangan, pp. 656662.

3. Healty. (2012). Percobaan Pemanfaatan Kromatografi Lapis Tipis Dalam Analisis Identifikasi Jamu Palsu. Ghalib, Jakarta :

4. LPPT. (2021). Laporan Kerja Uji Kimia. LPPT UGM. Yogyakarta.

5. Indriatmoko, D. D., Rudiana, T., \& Saefullah, A. (2019). Analisis
Kandungan Paracetamol Pada Jamu Pegal Linu Yang Diperoleh Dari Kawasan Industri Kecamatan Kibin Kabupaten Serang. Jurnal ITEKIMA, 5(1): pp. 33-47.

6. Farikha. (2016). Identifikasi Parasetamol dan Deksametason Dalam Jamu Reumatik dengan Metode KLT Dan Spektrofotometri UV di Pasar Minggu Palimanan Cirebon. Karya Tulis Ilmiah : Poltekkes Bandung.

7. Hayun., Leswara, N. D., \& Masrijal, C. (2007). Penetapan Kadar Triprolidina Hidroklorida dan Pseudoefedrina Hidroklorida dalam Sediaan Sirup Obat Influenza secara Kromatografi Lapis Tipis Densitometri. Majalah Ilmu Kefarmasian, 4(2), pp. 59-72. http://dx.doi.org/10.7454/psr.v4i2.341 $\underline{2}$

8. Pavia, D.L., Lampan, G.M., Kriz, G.S., dan Vyvyan, J.R., (2009). Introduction to Spectroscopy, Fourth Edition, Brooks/Cole, Washington, USA.

9. Silverstein, R.M., G.C. Bassler ang T.C. Morril. (1981). Spectrometric Identification Of Organic Compounds 4Th Edition Edn. John Wiley And Sons, New York.

10. Solomon, W. D. S., Anand, P. R. V., \& Shukla, R. (2010). Aplication of TLCDensitometri Method for Simultaneous Estimation of Tramadol $\mathrm{HCl}$ and Paracetamol in Pharmaceutical Dosage Forms. International Journal of ChemTech Research. 2(2).

11. Slamet, Setyo, U, D., \& Dewi, S. 2018. Identifikasi Kandungan Bahan Kimia Obat pada Jamu Rematik dan Asam 
Urat yang beredar di Kabupaten/Kota

Pekalongan secara Kualitatif.

URECOL STIKES PKU Muhammadiyah

Pekajangan.

12. Watson, David. (2009). Analisis Farmasi dalam terjemahan Syarief, W, R., EGC. Jakarta.

13. Ade, dkk. (2016). Pemeriksaan Kandungan Bahan Kimia Obat (BKO) Prednison pada Beberapa Sediaan Jamu Rematik. Jurnal Fitofarmaka Indonesia, 3(1), pp. 130-134. https://doi.org/10.330g6/jffi.v3i1.172

14. Badan Pengawas Obat dan Makanan Republik Indonesia. (2016). Bahaya Bahan Kimia Obat (BKO) yang Dibubuhkan ke dalam Obat Tradisional (Jamu). Accessed 23 August 2020.

15. Balitbangkes, 2014. Riset Sanitasi Jamu. Depkes. Jakarta.

16. BPOM RI. (2011). Keputusan Kepala Badan Obat dan Makanan No. 00.05.41.1384 Tentang Kriteria dan Tata Laksana Pendaftaran Obat Tradisional, Obat Herbal Terstandar, dan Fitofarmaka. Jakarta 